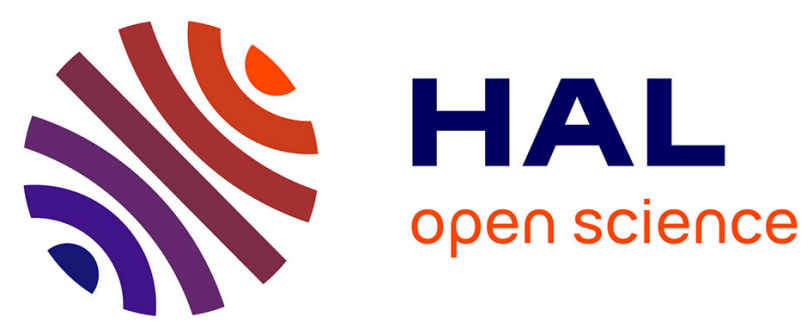

\title{
Characterizing potential flexibility in grassland use: An application to the French Aubrac area
}

\author{
Guillaume Martin, Laure L. Hossard, Jean Pierre J. P. Theau, Olivier \\ Therond, Etienne Josien, Pablo Cruz, Jean-Pierre Rellier, Roger \\ Martin-Clouaire, Michel M. Duru
}

\section{To cite this version:}

Guillaume Martin, Laure L. Hossard, Jean Pierre J. P. Theau, Olivier Therond, Etienne Josien, et al.. Characterizing potential flexibility in grassland use: An application to the French Aubrac area. Agronomy for Sustainable Development, 2009, 29 (2), pp.381-389. 10.1051/agro:2008063 . hal-02666273

\section{HAL Id: hal-02666273 \\ https://hal.inrae.fr/hal-02666273}

Submitted on 31 May 2020

HAL is a multi-disciplinary open access archive for the deposit and dissemination of scientific research documents, whether they are published or not. The documents may come from teaching and research institutions in France or abroad, or from public or private research centers.
L'archive ouverte pluridisciplinaire HAL, est destinée au dépôt et à la diffusion de documents scientifiques de niveau recherche, publiés ou non, émanant des établissements d'enseignement et de recherche français ou étrangers, des laboratoires publics ou privés. 


\title{
Research article
}

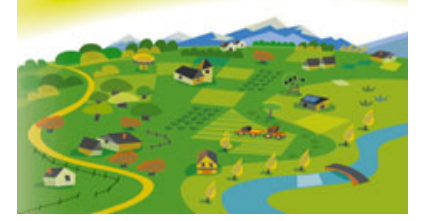

\section{Characterizing potential flexibility in grassland use. Application to the French Aubrac area}

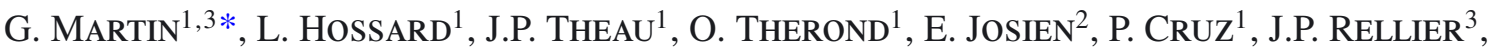 \\ R. MARTIN-CLOUAIRE ${ }^{3}$, M. DURU $^{1}$ \\ ${ }^{1}$ INRA, UMR 1248 AGIR, 31326 Castanet Tolosan, France \\ ${ }^{2}$ CEMAGREF, UMR Métafort, 63172 Aubière, France \\ ${ }^{3}$ INRA, UR 875 BIA, 31326 Castanet Tolosan, France
}

(Accepted 4 November 2008)

\begin{abstract}
Farmers increasingly need to adjust their management practices to accommodate unexpected events such as drought, and preserve the sustainability of their production. This flexibility requires background knowledge about where and when freedom of choice can be exercised. Here, we designed an analysis framework for grassland-based farming systems in mountainous and less-favored areas. An expert-based discrimination tree characterizes organizational flexibility by determining the range of possible types of grassland use under various topographic and farming constraints such as suitability for mechanization, and ease of access to a field. A set of time windows evaluates the timing flexibility in grassland use, each associated with a combination of a grassland community type and a type of grassland use. Our results show that the outputs of the discrimination tree match for 139 of 165 grassland fields, by comparison with field data obtained in the French Aubrac region. For a particular type of grassland use, the set of time windows proves that timing flexibility in grassland use between grassland community types can increase by 15 days over a 37 -day time range. When applying the two components of the analysis framework to a farm case, it shows that $24 \%$ of the farm area offers organizational flexibility, with several possibilities for grassland use. Timing flexibility for bringing forward or delaying the use of the grassland fields is unused in the farm. Most of the dates of grassland first use are similar irrespective of the diversity of grassland communities. The application of the analysis framework offers a sound evaluation of the potential flexibility to establish where and when it is possible to adjust management practices to cope with unexpected events. It can also be helpful in setting up coherent alternatives to the observed management strategies that can then be expanded in dynamic simulation models enabling deeper analysis.
\end{abstract}

mountainous areas / grassland use / organizational flexibility / timing flexibility / analysis framework

\section{INTRODUCTION}

\subsection{Rationale}

In mountainous or less-favored areas, farming systems are generally based on a diversity of permanent grasslands (Maurer et al., 2006; Andrieu et al., 2007). Grass production is highly variable in space and time, partly because of the variation in topography, grassland use and grassland community characteristics, and partly because of weather variability within and between years (Parsons, 1988; Maurer et al., 2006). Farmers have to manage the feeding of the herd in compliance with desired and attainable grass production. Configuring a farming system, i.e. allocating land areas over time to particular uses, and organizing production activities across time

* Corresponding author: gmartin@toulouse.inra.fr and space, is thus a complex task. This complexity is increasing due to the growing uncertainty surrounding livestock production, in particular due to climate change (Steinfeld et al., 2006). Climate change requires greater adaptive capacity of farmers in order to anticipate potential damage, to take advantage of opportunities, or to cope with the consequences. In particular, farmers have to adjust their management practices to actual conditions within the grazing season to achieve their objectives and preserve the longevity of their production project (Parsons, 1988; Ingrand et al., 2007; Kemp and Michalk, 2007). A shift towards greater flexibility (Dedieu et al., 2008) generates challenges for management in order to make it a means for accommodating unexpected or new events, e.g. drought or new agri-environmental schemes, and for creating opportunities for innovation in farm practices and improving the efficiency of the production system. The primary challenge posed by exploitation of flexibility is having 
the background knowledge about where and when freedom of choice can be exercised.

Flexibility in farming systems is gaining increasing importance in simulation-based approaches to farming system design (e.g. McCown et al., 1996). To evaluate the performance of management practices by simulation, one has first to articulate them in a management strategy scenario prior to the simulation. Integrating flexibility into a management strategy scenario to be evaluated by simulation requires a sound body of knowledge about the sources of flexibility in the farming systems, which should then support decisions about what to change, where and when. The sources of flexibility are of a very different nature (Ingrand et al., 2007; Dedieu et al., 2008): technical and organizational, e.g. the control of animal breeding; structural, e.g. the choice of a herd size and a stocking rate; and financial, e.g. the recourse to external revenue, etc. We focus on the technical and organizational flexibility related to grassland use.

\subsection{Sources of flexibility in grassland use}

Most research dealing with the management of forage shortages in grassland-based livestock systems consider the stocking rate as the key issue (e.g. Tichit et al., 2007). However, in less-favored areas, as emphasized by Caballero (2007), stocking rate is less of a problem than the spatio-temporal distribution of grazing. Farmers' willingness to modify grassland use on a given field to cope with unexpected or new events can be strongly constrained by the flexibility in grassland use in time and space on that field, which depends on planning on the farm scale. We focus on organizational flexibility and timing flexibility in grassland use, i.e. the spatial and the temporal dimensions of flexibility in grassland use.

Organizational flexibility determines the range of possible types of grassland use on a field. It is associated with various topographic and farming constraints. Distance from the field to the farmstead and between fields, field accessibility, size, presence of hedgerows, soil hydromorphy and slope, i.e. suitability for mechanization, have been identified among the determinants of land use in the French Plateau of Lorrain (Le Ber and Benoît, 1998), in the Netherlands (Carsjens and van der Knaap, 2002), in French Brittany (Thenail and Baudry, 2004) and in French Auvergne (Andrieu et al., 2007).

Timing flexibility in grassland use is the extent to which the use of a given grassland may be brought forward or deferred for a temporal interval at various times of year. It can be represented through a "time window" for grassland use. There is an optimal time window for using grassland of a given community type, i.e. the structure and composition of a plant community, depending on its biomass availability and/or digestibility and herd feeding objectives (Dale et al., 2008). This time window has to be compatible with the creation or renewal of particular grassland community characteristics (Kemp and Michalk, 2007). With stable plant mineral nutrition, using the grass for grazing or cutting within this time window should ensure sustainable long-term production by keeping the grassland in a dynamic equilibrium (Huston, 1994). Timing flexibility in grassland use varies between grassland community types (Duru et al., 2008), which are mainly determined by management, e.g. nutrient resource availability and grassland use (Lavorel and Garnier, 2002) and, to a lesser extent, by other factors such as the type of grazing animals (Bakker et al., 2006). We focus on the relations between type of grazing animals, type of grassland use and timing flexibility in grassland use together with grassland community characteristics. These characteristics in turn influence choices for type and timing of grassland use.

\subsection{Originality and objectives of the article}

The question of organizing grassland-based livestock systems under a range of spatio-temporal constraints has received little attention. Even in the field of cropping system planning, approaches are either focused on spatial constraints (e.g. Le Ber and Benoit, 1998) or temporal constraints (e.g. Dogliotti et al., 2003) but never both at once. Applied to grassland-based livestock systems in mountainous or lessfavored areas, the few published findings analyze the observed grassland use on the farm scale either from a topographic and farming constraints angle (Brunschwig et al., 2006) or from the point of view of grassland community characteristics (Duru et al., 2005). As far as we know, no articles consider, in analyzing grassland use planning, the two sources of flexibility, i.e. organizational flexibility and timing flexibility in grassland use. These concerns are at the core of the analysis framework presented in this article. Unlike Groot et al. (2007), our aim is not to find the optimal land use systems that satisfy a range of objectives, but to provide practical information for characterizing the farmer's scope for adapting the grassland system to particular conditions occurring during spring. This is of major interest for researchers involved in the design of innovative farming systems, providing them with guidelines to design reliable and feasible alternatives to the observed management strategies prior to their evaluation by simulation.

In this article, we describe the design and application of the analysis framework for mountainous or less-favored areas. It is made up of two components: (i) an expert-based, as opposed to data-and-statistics-based, discrimination tree of possible types of grassland use under certain topographic and farming constraints to evaluate organizational flexibility, and (ii) a set of time windows to evaluate timing flexibility in grassland use, each associated with a combination of a grassland community type and a type of grassland use. The analysis framework is applied to data collected in eight farms of the French Aubrac region. In the last section, a focus on one of these farms emphasizes the emerging knowledge brought by the concomitant analysis of organizational flexibility and timing flexibility in grassland use.

\section{MATERIALS AND METHODS}

\subsection{Design of the analysis framework}

Characterization of organizational flexibility in grassland use was an iterative process involving six scientists and three 
experts, all co-authors, for several successive meetings. Based on the existing literature on the topic (Le Ber and Benoît, 1998; Carsjens and van der Knaap, 2002; Thenail and Baudry, 2004; Andrieu et al., 2007) and the empirical knowledge of the research team, we listed the topographic and farming constraints involved in the allocation of a type of grassland use in mountainous or less-favored areas. We ended up with a number of Boolean conditions linked to functional indicators and generic and meaningful characteristics. As an example, an altitude threshold for characterizing so-called summer grasslands was replaced by the capacity of a field to supply green fodder during summer; this attribute is actually directly linked to the specific use of those fields, unlike an altitude threshold. Then, also based on expert knowledge, we established a hypothetical hierarchy between these characteristics to account for their degree of importance for farmers when allocating a type of grassland use to a field. Those combinations of characteristics that did not make sense were removed from the discrimination tree. Finally, we synthesized and ordered this knowledge by arranging the characteristics in a discrimination tree of possible types of grassland use, i.e. one or more, depending on the level of organizational flexibility. The relevance and scope of the empirical agronomic knowledge synthesized in the tree was further evaluated by comparison with observed data (see Sect. 3.1).

For grazing, type of grassland use was expressed by the type of grazing animals. Grazing animals were categorized as follows. Animals for production included milking cows in dairy systems, and heifers, steer calves and suckler calves if sold young, i.e. 9 months, in beef systems. Animals for replacement or out of their production period which require less care and attention were heifers and dry cows in dairy systems, and suckler cows if calves are not sold young, i.e. 9 months, in beef systems.

Recent advances in production and functional plant ecology have made it possible to characterize timing flexibility in grassland use. The concept of functional diversity is based on the definition and measuring of plant traits, i.e. morphological, physiological and phenological plant characteristics, in response to availability of resources and perturbations (Diaz and Cabido, 2001). According to Grime's biomass ratio hypothesis (Grime, 1998), taking into account only the most dominant species of a plant community would be sufficient to describe response to environmental change. Grasses usually represent a large proportion of the biomass in speciesrich grasslands. In addition, it has been shown that legumes and forbs mimic the dynamics of grass species within a plant community (Duru et al., in press). The leaf dry matter content of individual species as well as abundance-weighted mean leaf dry matter content across grass species are well correlated with agronomic characteristics such as organic matter digestibility and plant phenology that govern the dynamics of grass growth (Duru et al., 2005; Al Haj Khaled et al., 2006; Da Pontes et al., 2007). Leaf dry matter content measurements rank species in the same order regardless of the frequency of defoliation (Da Pontes et al., 2007) and nutrient availability (Al Haj Khaled et al., 2005), and across years and sites (Garnier et al., 2001). Given all these features, an abundanceweighted mean leaf dry matter content across grass species provides a powerful descriptor of a grassland community for characterizing the timing flexibility through the time windows for grassland use (Duru et al., 2008).

When comparing technical operations between fields and farms in semi-mountainous areas, a major problem is the time scale. Fields are at various altitudes, so that at a given Julian date, herbage age and phenology will vary. To account for this variation, time is expressed as thermal time or growing degree-day sums, i.e. the accumulated daily mean temperature between $0{ }^{\circ} \mathrm{C}$ and $18{ }^{\circ} \mathrm{C}$ starting from the 1 st of February. Air temperatures are assumed to fall by $0.6^{\circ} \mathrm{C}$ per $100 \mathrm{~m}$ compared with the reference daily mean temperature measured at a fixed altitude (Cros et al., 2003).

The use of an abundance-weighted mean leaf dry matter content across grass species combined with thermal time offered a basis for comparing the observed thermal time at first use on the surveyed grasslands for a range of grassland community types. For a given region, observations over a wide range of grasslands provided a reliable picture of the diversity of thermal time at first use for the average climatic year associated with each observed combination of grassland use and community type. The earliest date for grassland first use marked the beginning of the thermal time window, while the latest closed this window.

\subsection{Application to the Aubrac region}

\subsubsection{Case study}

The work was carried out in the Aubrac region in the southern part of the French Central Massif $\left(2.85^{\circ} \mathrm{E}, 44.68^{\circ} \mathrm{N}\right)$. It covers an area of about $40 \mathrm{~km} \times 20 \mathrm{~km}$ with an altitude range of $800-1400 \mathrm{~m}$. The climate is montane with long winters characterized by heavy snowfalls that determine turnout and wintering dates. Average yearly temperature is $9{ }^{\circ} \mathrm{C}$. Average yearly precipitation, i.e. $1312 \mathrm{~mm}$, is well distributed, with 107 rainy days per year. Most of the area is occupied by temporary and permanent grasslands with dairy and beef livestock.

In choosing the sample farms, we did not attempt to choose farms which were particularly representative of the zone by using statistical methods. Instead, we tried to capture the diversity of management of the local farming systems by choosing farms located on a gradient of intensification depending on farmers' use of mineral fertilizers, grazing methods and haymaking practice, i.e. herbage phenological stage and overall stocking rate for subsequent diversity in field management intensity. Silage is not made in the zone, due to Protected Designation of Origin specification. The farms also had to be similar in their availability of machinery and labor per animal unit. As the survey involved arduous field work, we restricted our analysis to four beef farms and four dairy farms (Tab. I), selected with the assistance of local extension services. To simplify the analysis, we surveyed a range of quite standardized farms as regards animal production, i.e. farms with similar animal breeds and similar animal categories with comparable feeding requirements. Thus, in our analysis we do not consider differences in herd feeding objectives that could affect the determination of the thermal time windows for grassland first use. 
Table I. Main characteristics of the four dairy farms and four beef farms surveyed. Stocking rate at turnout was calculated based on the available area close to the cowshed at turnout. Structural descriptors such as area, number of cows, size of the herd and altitude range of the farm fields differ between farms. In addition, farms are located on a gradient of intensification of stocking rate, confirming the diversity of management of the surveyed farms.

\begin{tabular}{|c|c|c|c|c|c|c|c|c|}
\hline Farm & Bat & Dag & Pou & Sal & Dar & Del & Mou & Nie \\
\hline Production & Dairy & Dairy & Dairy & Dairy & Beef & Beef & Beef & Beef \\
\hline Summer pastures (ha) & 0 & 15 & 18 & 28 & 38 & 0 & 63 & 106 \\
\hline Number of cows & 40 & 38 & 48 & 35 & 56 & 44 & 48 & 64 \\
\hline Number of animal units & 60 & 56 & 69 & 52 & 134 & 104 & 111 & 144 \\
\hline Stocking rate (ha/animal units) & 0.90 & 1.04 & 1.10 & 1.33 & 0.78 & 0.71 & 1.05 & 1.33 \\
\hline Number of fields considered in the study & 17 & 22 & 16 & 21 & 26 & 25 & 18 & 20 \\
\hline Proportion of surface area considered in the study (\%) & 78 & 69 & 57 & 87 & 84 & 88 & 93 & 88 \\
\hline
\end{tabular}

\subsubsection{Characterization of grassland use and of the topographic and farming constraints}

The first stage of the survey was to record topographic and farming information for each field, i.e. area, altitude, distance to the cowshed and ease of access for a herd batch coming from the cowshed or the neighboring field, and suitability for mechanization. Next we identified the farmer's past and present grassland use practices on the fields concerned: fertilizer applied, type and date of the first use in spring for the average climatic year, type of grazing animals. These records enabled us to exclude those grasslands that were not considered at equilibrium (sensu Huston, 1994), i.e. abandoned or irregularly used, for the subsequent steps of data collection.

\subsubsection{Characterization of grassland community types}

A floristic survey using the frequency-rank method was conducted over the 165 fields of the eight surveyed farms. The survey was used to estimate an abundance-weighted mean leaf dry matter content across grass species $\left(\mathrm{LDMC}_{\mathrm{g}}\right)$ for each sampled grassland field, based solely on the grass species' leaf dry matter content values, as $\mathrm{LDMC}_{\mathrm{g}}=\sum_{\mathrm{i}} \mathrm{p}_{\mathrm{i}} \cdot \mathrm{LDMC} \mathrm{C}_{\mathrm{i}}$ where $\mathrm{p}_{\mathrm{i}}$ is the relative abundance of the ith grass species and $\mathrm{LDMC}_{\mathrm{i}}$ is the leaf dry matter content of the ith grass species determined from a leaf dry matter content database (Al Haj Khaled et al., 2005). A Shapiro Wilk test on the data did not reject the null hypothesis $(P=0.605)$ that the data are normally distributed. Given the normal distribution of the data and the range of standard deviations in leaf dry matter content generally found in the literature (e.g. Al Haj Khaled et al., 2005), we divided the axis of abundance-weighted mean leaf dry matter content across grass species into four classes of equal range, i.e. $201-215 \mathrm{mg} . \mathrm{g}^{-1}, 216-230 \mathrm{mg} \cdot \mathrm{g}^{-1}, 231-245 \mathrm{mg} \cdot \mathrm{g}^{-1}$ and $246-260 \mathrm{mg} \cdot \mathrm{g}^{-1}$. The relevance of this classification was confirmed by an analysis of variance $(P<0.001)$ displaying a high inter-group variance (Mean Square $=17626 ; \mathrm{df}=3$ ) and a low intra-group variance $($ Mean Square $=2619 ; \mathrm{df}=162$ ).

\section{RESULTS AND DISCUSSION}

\subsection{Characterization of organizational flexibility in grassland use}

The research team identified five topographic and farming constraints as the main determinants of the range of possible types of grassland use in mountainous or less-favored areas. These five constraints were mainly field properties and one condition associated with herd batching. Listed in an expertbased order of importance as to when to allocate a type of grassland use to a field, these five constraints are:

(1) Possibility of daily return to the cowshed, which is mainly determined by the presence of an obstacle between the grassland field and the cowshed, i.e. road, forest, etc. or a long distance. Fields suited to a daily return are first used at turnout for both dairy and beef systems. They are reserved for the categories of animals requiring the most care, e.g. a supply of concentrates and water, especially in dairy systems with cows that need to be milked twice a day.

(2) Ease of access of a field from the closest one is a key factor for determining the type of grassland use of fields on which daily return to the cowshed is not possible. If such a field does not permit the move to the closest field without transport then it is isolated and further elements, e.g. surface area per animal unit, should be considered to determine its type of grassland use.

(3) Suitability for mechanization; this determines whether the field can be mowed.

(4) Sufficient surface area to feed five animal units per hectare during three days in spring; this determines whether an isolated field can be used for grazing. Such fields require the herd batch to be transported. Thus, the grassland field should provide enough fodder to satisfy the needs of a fiveanimal-unit herd batch for at least three days before having to move on. Otherwise, isolated fields may hardly be used for grazing.

(5) The capacity of the field to supply green fodder during summer is of major importance in European semimountainous areas where the summer months are the 


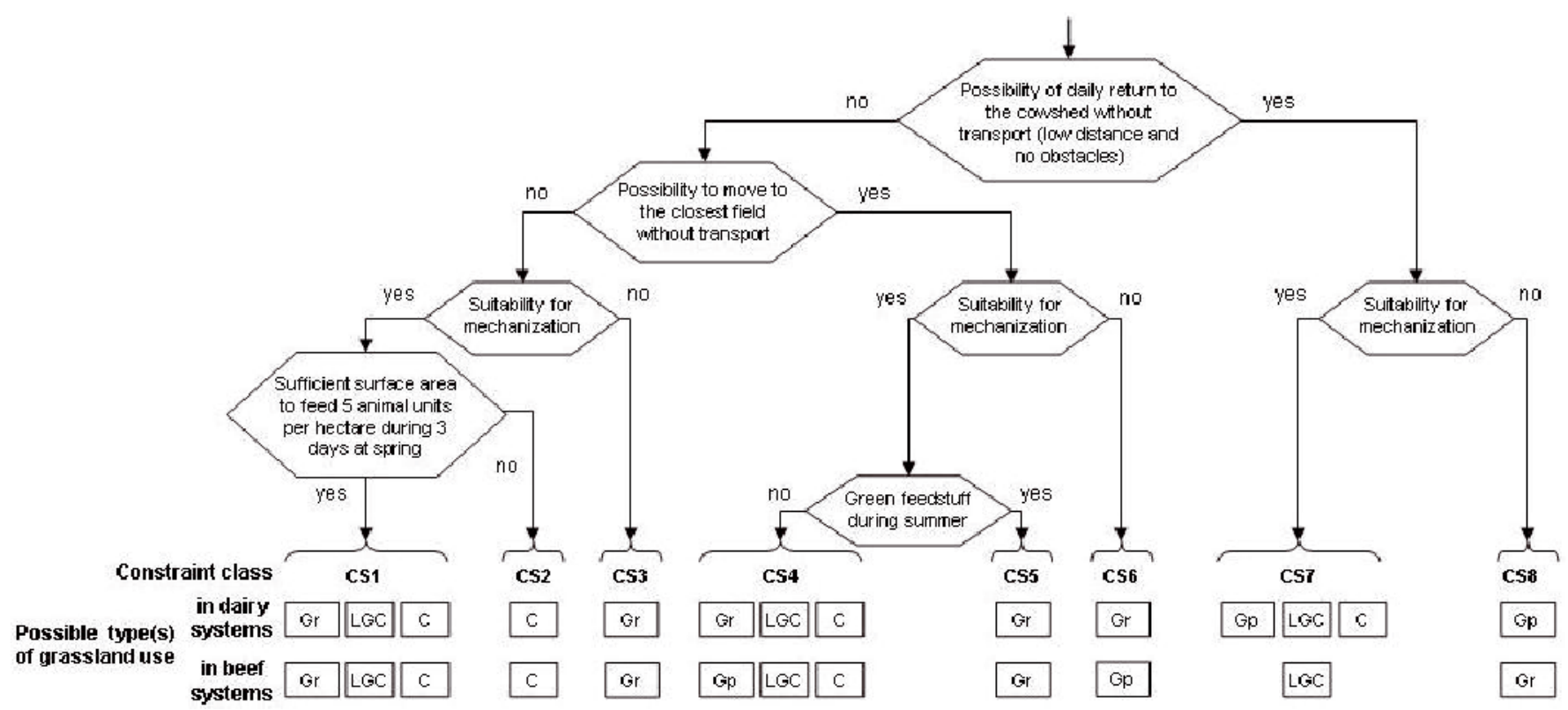

Figure 1. An expert-based discrimination tree of grassland use opportunities according to the topographic and farming constraints of the field. Five topographic and farming constraints are listed in a hierarchical order and result in pathways of constraints named constraint classes (CS). Regarding the daily return to the cowshed without transport, obstacles can be roads, forests, etc. Those combinations of constraints that did not make sense were removed from the discrimination tree. For each constraint class a single or a range of possible grassland uses in spring is specified for dairy and beef systems. Types of grassland use are: Gp, grazing by animals for production; Gr, grazing by animals for replacement; LGC, light grazing followed by cutting; C, cutting. When compared with data gathered over 165 fields, the discrimination tree fits well with the observed type of grassland use for 139 fields. This discrimination tree gives the proportions of multiple and single grassland use fields, the former being a source of organizational flexibility.

driest. Hence, grasslands that are shallow or located at the highest altitudes are generally kept out of the grazing chain during early spring to preserve green standing herbage for late spring and summer.

Not all combinations of constraints were considered. For example, the possibility of moving to the closest field without transport does not make sense when daily return to the cowshed from the field is possible. Indeed, there would be other fields to which the herd could be moved in such conditions. Thus, the condition associated with a minimum three-day stay for a five-animal-unit herd batch also does not make sense if it is possible to move the herd batch easily.

The resulting discrimination tree (Fig. 1) identifies several types of grassland use in some cases, e.g. the CS1 constraint class, but a single one in other conditions when grassland use is much more constrained, e.g. CS2 constraint class. Types of grassland use were assumed to be dependent on the farm production, i.e. dairy or beef. In beef systems, fields are generally more scattered than in dairy systems, and lie at different altitudes. Thus, in beef systems, summer grasslands play a major role in the feeding system. At turnout, scarcity of land close to the cowshed results in a high grazing pressure in relation to the vegetation growth capacity (Tab. I). The fields are lightly grazed for about one month before animals for replacement are moved to summer grasslands and stocking rates decrease around the farm to save fields of constraint class CS7 for the cutting operation following a light grazing. Thus, in beef systems, for grassland fields of constraint class CS7, light grazing followed by cutting is the only possibility (Fig. 1). Dairy systems generally have more fields near the cowshed, so that grazing pressure around the cowshed at turnout is slightly lower than for beef systems (Tab. I), and other types of grassland use are possible as part of the area can be preserved for cutting from the beginning of the grazing season.

This discrimination tree identifies the proportions of multiple and single use grassland fields, the former being a source of organizational flexibility. To generate such a model, the decision to use an expert-based approach rather than a classification and regression approach was not trivial. The dataset was not exhaustive enough to ensure the generic nature of a tree generated with such classification and regression approaches. In addition, tree models generated with software programs implementing these approaches do not necessarily have a logical succession of criteria (Darnhofer et al., 1997 cited by Darnhofer et al., 2005). Manually drawn models can be more accurate (Darnhofer et al., 2005) as they are enriched by the experience of the persons involved in the design, thereby adding information gathered in various conditions over years not necessarily contained in a database. As an example (Fig. 1), the traditional view of considering suitability for mechanization as the main determinant of possible type of grassland use was thwarted when focusing on the 
Table II. Minimum and maximum thermal time at first use and the corresponding range for each combination of grassland use and class of abundance-weighted mean leaf dry matter content across grass species (LDMC $\mathrm{g}_{\mathrm{g}}$. For light grazing followed by cutting, two values are provided, one for light grazing and another for the subsequent cutting event. NA means not available. When the number of observations is sufficient, i.e. up to five, for each type of grassland use, the range of thermal time at first use increases with the LDMCg class, offering greater timing flexibility.

\begin{tabular}{|c|c|c|c|c|c|}
\hline $\begin{array}{l}\text { Type of } \\
\text { grassland use }\end{array}$ & $\begin{array}{l}\text { LDMCg } \\
\text { Class }\end{array}$ & $\begin{array}{l}\text { Minimum } \\
\text { thermal time } \\
\text { at first use } \\
\left({ }^{\circ} \mathrm{C} \cdot \mathrm{d}^{-1}\right)\end{array}$ & $\begin{array}{l}\text { Maximum } \\
\text { thermal time } \\
\text { at first use } \\
\left({ }^{\circ} \mathrm{C} \cdot \mathrm{d}^{-1}\right)\end{array}$ & $\begin{array}{c}\text { Range of } \\
\text { thermal time } \\
\text { at first use } \\
\left({ }^{\circ} \mathrm{C} \cdot \mathrm{d}^{-1}\right)\end{array}$ & $\begin{array}{l}\text { Number of } \\
\text { observations }\end{array}$ \\
\hline \multirow{3}{*}{ Cutting } & 2 & 904 & 1553 & 650 & 26 \\
\hline & 3 & 965 & 1489 & 525 & 2 \\
\hline & 4 & 1489 & 1489 & NA & 1 \\
\hline \multirow{2}{*}{$\begin{array}{l}\text { Light grazing followed } \\
\text { by Cutting }\end{array}$} & 3 & $445-1238$ & $445-1238$ & NA & 1 \\
\hline & 4 & $353-1459$ & $353-1459$ & NA & 1 \\
\hline Grazing & 1 & 557 & 661 & 104 & 3 \\
\hline by animals & 2 & 396 & 905 & 509 & 36 \\
\hline for production & 3 & 407 & 1024 & 617 & 22 \\
\hline Grazing & 2 & 321 & 602 & 281 & 6 \\
\hline
\end{tabular}

configuration of the farming system and the organization of production activities. The possibility of daily return to the cowshed was found to be more critical in this case.

Tested on the data gathered for the 165 fields of the case study, the discrimination tree fitted well with the observed type of grassland use for 139 fields, or $85 \%$ of the total area of surveyed grassland fields. Several solutions were possible for certain pathways in the tree. Thus, proper statistical evaluation of the tree was not possible due to risks of overfitting. However, given the objectives associated with the discrimination tree, i.e. identifying the range of possible solutions rather than the most frequent one, such a test confirmed the relevance and scope of the empirical agronomic knowledge used to construct the tree, and the satisfactory performance obtained with the degree of complexity included in the tree, i.e. only five topographic and farming constraints, and seven constraint classes. The remaining 26 fields were spread over four beef and two dairy farms and were representative of exceptions, including, for instance, the case of a farm suffering from a shortage of area suitable for cutting, which forced hay-making on summer grasslands, or specific cases such as a field which is inaccessible until the neighboring field is cut.

A key factor in trying to grasp the diversity of farming practices lies in the reliability of the representation of local farmers' perception of their land resources. The experiences of scientists and experts involved in the research could have been strongly influenced by their long experience in southwestern and central France. This may limit the capacity of the expertbased discrimination tree to be easily and reliably applied to other European mountainous areas.

For simulation-based approaches to farming system design, there are no methodologies or models for planning feasible and suitable spatial organizations of grassland use. Such a tree could provide the means for choosing alternatives for further investigation by simulation of a system's robustness to unusual circumstances or weather events.

\subsection{Characterization of timing flexibility in grassland use}

For each type of grassland use we tested the use of thermal time at first use together with abundance-weighted mean leaf dry matter content across grass species for the 165 fields of the case study. The range of thermal time for grassland first use increased with the classes of abundance-weighted mean leaf dry matter content across grass species when the number of observations was sufficient, i.e. up to five (Tab. II). Taking the example of light grazing before a cut, the range of thermal time for grassland first use changed from $221^{\circ} \mathrm{C} . \mathrm{d}^{-1}$ to $366^{\circ} \mathrm{C} \cdot \mathrm{d}^{-1}$ when changing the grassland community type. In spring, this corresponds roughly to time windows of about 22 and 37 days. Similar to this example, when increasing the class of abundance-weighted mean leaf dry matter content across grass species, the range of thermal time for grassland first use, i.e. timing flexibility, increased from $551^{\circ} \mathrm{C} . \mathrm{d}^{-1}$ to $650{ }^{\circ} \mathrm{C} . \mathrm{d}^{-1}$, from $509{ }^{\circ} \mathrm{C} . \mathrm{d}^{-1}$ to $617{ }^{\circ} \mathrm{C} . \mathrm{d}^{-1}$ and from $281{ }^{\circ} \mathrm{C} . \mathrm{d}^{-1}$ to $541{ }^{\circ} \mathrm{C} . \mathrm{d}^{-1}$ depending on the type of grassland use (Tab. II). For one case only, the expected widening in timing flexibility in grassland use was not observed, i.e. for fields with a grassland community belonging to class 4 of abundance-weighted mean leaf dry matter content for grass that were grazed by animals for replacement (last line in Tab. II). Almost all these fields were summer grasslands located at the highest altitudes. On these summer grasslands, stocking rate was very low to compensate for lower temperatures that slowed vegetation growth, thereby delaying the time 
to reach particular phenological stages. This is why the results obtained in this case were not very different from those obtained with grazing by animals for replacement and class 3 of abundance-weighted mean leaf dry matter content across grass species.

This dependence between grassland community type and thermal time window for each type of grassland use has already been described in theory (Duru et al., 2008). This is the first attempt to confirm it with observed farmers' practices. The validation of this hypothesis offers interesting prospects for classifying grassland use practices in the field of ecology. Currently, most published findings study the effect of one type of grassland use and classify it according to frequency of use (e.g. Da Pontes et al., 2007). Actually, plant traits respond not only to a single factor but to the occurrence of this factor within a time period. The approach combining thermal time at first use and abundance-weighted mean leaf dry matter content across grass species seems especially suited to characterizing this time range.

Considering that the sample grasslands were at equilibrium, using grassland within the thermal time windows might ensure the longevity of the grassland community over the long term. The limited number of grassland surveys means that these temporal reference points cannot safely be applied beyond our study area. Further surveys should be conducted to determine whether grassland use outside these thermal time windows might endanger the long-term sustainability of the grassland community. Still, the tendency toward increased timing flexibility in grassland use associated with high abundanceweighted mean leaf dry matter content across grass species was confirmed. Definition of the thermal time windows for each region based on surveys of grasslands at equilibrium could provide recommendations for sustainable exploitation of grasslands.

\subsection{A farm-scale analysis of potential flexibility in grassland use}

We selected the most extensively surveyed beef farm (Mou in Tab. I) for applying the two components of the analysis framework to characterize potential flexibility in grassland use. When projected in the discrimination tree of Figure 1, farm Mou has 63 ha, i.e. fields number 11, 12 and 13 corresponding to summer grasslands in constraint class CS5 that can only be grazed by animals for replacement with low care requirements (Fig. 2). Another 19.6 ha, i.e. fields of constraint classes CS2 and CS7, are only suited for cutting or a light grazing followed by a cut. The remaining 25.9 ha taken into account in the survey, i.e. fields of constraint classes CS1 and CS4, offer organizational flexibility due to several possible types of grassland use, or $24 \%$ of the area considered in the study. By comparison, farms Nie and Del have $17 \%$ and $98 \%$, respectively.

When several possibilities for grassland use exist for a given class of topographic and farming constraints, preferential grassland use also depends on the land area available in the other constraint classes and for other types of grassland use. Indeed, sufficient area is needed to ensure wintering forage stocks. Of the area suited to a single possible type of grassland use, six fields (numbers 2, 5, 6, 7, 8 and 9) are cut. Fields number 1, 3 and 4, usually grazed, can be used for haymaking to compensate for forage deficits when needed, whereas fields number 2, 5, 6, 7, 8 and 9 still represent additional grazable fodder in case of early drought.

Projections in the thermal time range for grassland first use (Fig. 2) for each combination of type of grassland use and grassland community type revealed that farm Mou has most of its date of grassland first use concentrated around the same thermal time irrespective of the diversity of grassland communities. As an example, cutting events on fields number 5, 6, 7 and 8 occur almost on the same dates despite different grassland community types. For each combination of grassland use and grassland community type, other farms such as Dar show a spread of grassland first uses over the entire thermal time range. There is flexibility currently unused in farm Mou for bringing forward or delaying the use of the grassland fields such as in the case of drought, for example, by anticipating the cutting of field number 6 in order to open up additional grazable area.

The application of the analysis framework to farm Mou offers a sound evaluation of the potential flexibility for adjusting management practices to cope with unexpected events. Aspects of flexibility not considered in our analysis, such as recourse to fertilization, additional machinery or labor, and herd batching may constitute additional ways to accommodate unexpected events. Our analysis is limited to considerations for spring use. The use of grasslands in summer and autumn might be conditioned by the nature of spring use, especially the thermal time windows. Further improvements are needed to provide an overview of the potential flexibility over the course of the year. Nevertheless, the analysis framework constitutes a novel base for evaluating and comparing the spring potential flexibility in space and time between farms. In characterizing the adaptive capacities of farms, the framework indicates which aspect of flexibility is preferable to employ on a farm faced with an unexpected event in order to ensure its sustainability.

\section{CONCLUSION}

The analysis framework presented in this article is a novel way of efficiently characterizing potential flexibility in grassland use on farms in mountainous or less-favored areas. It indicates where and when management practices can be adjusted to cope with unexpected events by evaluating organizational flexibility and timing flexibility in grassland use. In the field of farming system design, organizing agricultural systems and the related production activities under a range of spatial and temporal constraints is a common problem. The quest towards more sustainable farming systems requires methods to design such systems while satisfying these constraints. To ensure the credibility of the outputs, exploration by farm-scale simulation requires reliable facts on which to build the alternative strategies to be tested. Our analysis framework provides 


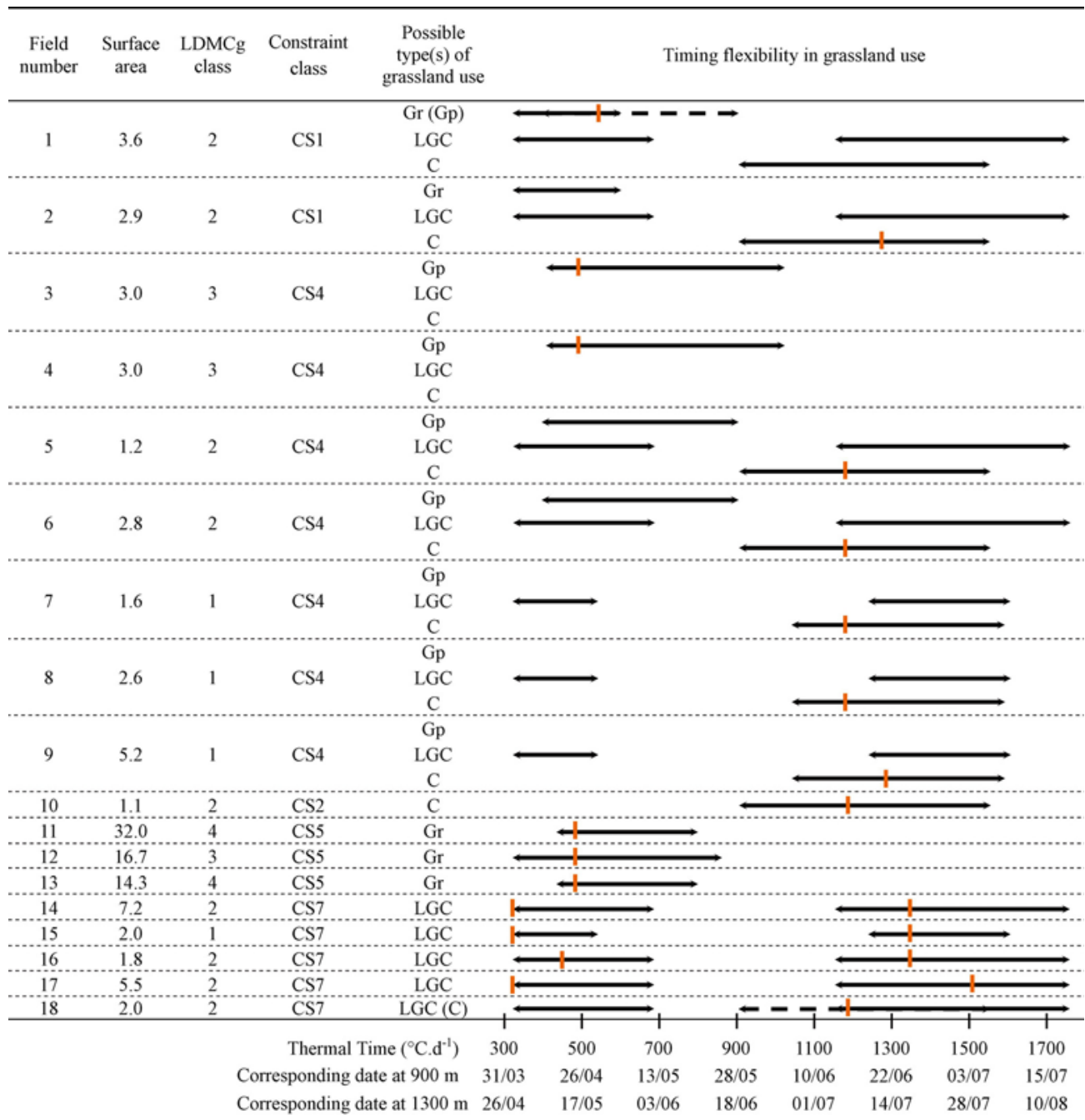

Figure 2. Overview of organizational flexibility and timing flexibility in grassland use for each field in farm Mou. Types of grassland use are: Gp, grazing by animals for production; Gr, grazing by animals for replacement; LGC, light grazing followed by cutting; C, cutting. Horizontal arrows correspond to the thermal time windows for grassland spring use for each type of grassland use and class of abundance weighted-mean leaf dry matter content across grass species (LDMCg) as presented in Table II. Vertical lines represent the observed thermal time at first use for each field. Indications of the Julian date at $900 \mathrm{~m}$ and $1300 \mathrm{~m}$ corresponding to the thermal time scale marks for the average climatic year are specified below the thermal time axis. For fields 1 and 18, the type of grassland use conveyed by the tree of Figure 1 does not match with the observed use in brackets. Corresponding thermal time windows for grassland use are the dashed arrows. When sufficient data were not available in Table II, arrows were not drawn, such as for cutting on Field 11A. The analysis framework shows that Farmer Mou has organizational flexibility, i.e. several possible types of grassland use, on $24 \%$ of the area considered in the study. He also has unused flexibility for bringing forward or delaying the use of the grassland fields but he concentrates the first uses around the same thermal time irrespective of the diversity of grassland communities.

such information. It may be used as a first step for pointing out the conditional adaptations to the production plan (Garcia et al., 2005) that should be tested in simulation scenarios. In this way, dynamic simulation modeling could allow flexible management strategies suited to ensuring the sustainability of farming systems in the face of unexpected events to be identified. Exploitation of flexibility at field level depends on considerations on the farm scale, such as availability of labor and machinery. Verifying the consistency and feasibility of the flexible management strategies to be tested can only be achieved by simulating the dynamic implementation of the farm management activities. This can hardly be done with an ex-ante analysis. That is why the analysis framework is a component of a larger simulation project (Martin et al., 2008) aiming at designing sustainable grassland-based livestock farming systems.

Acknowledgements: The work presented in this publication is funded by the French ANR ADD projects TRANS (TRANSformations de l'élevage et dynamiques des espaces - ANR-05-PADD003), PRODDIG (PROmotion du Développement Durable par les 
Indications Géographiques - ANR-05-PADD-012) and VALIDATE (Vulnerability Assessment of LIvestock and grasslanDs to climAte change and exTreme Events - ANR-07-VULN-011). The authors are grateful to the eight farmers involved in the study for their fruitful collaboration, their time, and their investment. We thank Alan Scaife for the English revision and the anonymous reviewers for their helpful comments.

\section{REFERENCES}

Al Haj Khaled R., Duru M., Theau J.P., Plantureux S., Cruz P. (2005) Variation of leaf traits through seasons and $\mathrm{N}$-availability levels and its consequences for ranking grassland species, J. Veg. Sci. 16, 391-398.

Al Haj Khaled R., Duru M., Decruyenaere V., Jouany C., Cruz P. (2006) Using leaf traits to rank native grasses according to their nutritive value, Rangeland Ecol. Manag. 59, 648-654.

Andrieu N., Josien E., Duru M. (2007) Relationships between diversity of grassland vegetation, field characteristics and land use management practices assessed at the farm level, Agr. Ecosyst. Environ. 120, 359-369.

Bakker E.S., Ritchie M.E., Olff H., Milchunas D.G., Knops J.M.H. (2006) Herbivore impact on grassland plant diversity depends on habitat productivity and herbivore size, Ecol. Lett. 9, 780-788.

Brunschwig G., Josien E., Bernhard C. (2006) Contraintes géographiques et modes d'utilisation des parcelles en élevage bovin laitier et allaitant, Fourrages 185, 83-95.

Caballero R. (2007) High Nature Value (HNV) Grazing Systems in Europe: A Link between Biodiversity and Farm Economics, Open Agr. J. 1, 11-17.

Carsjens G.J., van der Knaap W. (2002) Strategic land-use allocation: dealing with spatial relationships and fragmentation of agriculture, Landscape Urban Plan. 58, 171-179.

Cros M.J., Duru M., Garcia F., Martin-Clouaire R. (2003) A biophysical dairy farm model to evaluate rotational grazing management strategies, Agronomie 23, 105-122.

Da Pontes L.D., Soussana J.F., Louault F., Andueza D., Carrere P. (2007) Leaf traits affect the above-ground productivity and quality of pasture grasses, Funct. Ecol. 21, 844-853.

Dale A.J., Mayne C.S., Laidlaw A.S., Ferris C.P. (2008) Effect of altering the grazing interval on growth and utilization of grass herbage and performance of dairy cows under rotational grazing, Grass Forage Sci. 63, 257-269.

Darnhofer I., Schneeberger W., Freyer B. (2005) Converting or not converting to organic farming in Austria: Farmer types and their rationale, Agr. Human Values 22, 39-52.

Dedieu B., Chia E., Leclerc B., Moulin C.H., Tichit M. (2008) (Eds.), L'élevage en mouvement. Flexibilité et adaptation des exploitations d'herbivores, Quae, Versailles.

Diaz S., Cabido M. (2001) Vive la difference: plant functional diversity matters to ecosystem processes, Trends Ecol. Evol. 16, 646-655.

Dogliotti S., Rossing W.A.H., van Ittersum M.K. (2003) ROTAT, a tool for systematically generating crop rotations, Eur. J. Agron. 19, 239250.

Duru M., Tallowin J., Cruz P. (2005) Functional diversity in low-input grassland farming systems: characterisation, effect and management, Agron. Res. 3, 125-138.

Duru M., Al Haj Khaled R., Ducourtieux C., Theau J.P., de Quadros F.L.F., Cruz P., Do plant functional types based on leaf dry matter content allow characterizing native grass species and grasslands for herbage growth pattern? Plant Ecol., in press, doi:10.1007/s11258008-9516-9.

Duru M., Cruz P., Magda D. (2008) La conduite des couverts prairiaux, source de flexibilité, in: Dedieu B., Chia E., Leclerc B., Moulin C.H., Tichit M. (Eds.), L'élevage en mouvement. Flexibilité et adaptation des exploitations d'herbivores, Quae, pp. 57-72.

Garcia F., Guerrin F., Martin-Clouaire R., Rellier J.P. (2005) The human side of agricultural production management - the missing focus in simulation approaches, in: Proceedings of the MODSIM 2005 Conference, Melbourne, Australia, pp. 203-209.

Garnier E., Laurent G., Bellmann A., Debain S., Berthelier P., Ducout B., Roumet C., Navas M.L. (2001) Consistency of species ranking based on functional leaf traits, New Phytol. 152, 69-83.

Grime J.P. (1998) Benefits of plant diversity to ecosystems: immediate, filter and founder effects, J. Ecol. 86, 902-910.

Groot J.C.J., Rossing W.A.H., Jellema A., Stobbelaar D.J., Renting H., van Ittersum M.K. (2007) Exploring multi-scale trade-offs between nature conservation, agricultural profits and landscape quality $-\mathrm{A}$ methodology to support discussions on land-use perspectives, Agr. Ecosyst. Environ. 120, 58-69.

Huston M.A. (1994) (Eds.) Biological diversity. The coexistence of species on changing landscapes, Cambridge Univ. Press.

Ingrand S., Bardey H., Brossier J., Dedieu B., Degrange B., Lémery B., Pasdermadjian P. (2007) Flexibility of suckler cattle farms in the face of uncertainty within the beef industry: a proposed definition and an illustration, J. Agr. Educ. Ext. 13, 39-48.

Kemp D.R., Michalk D.L. (2007) Towards sustainable grassland and livestock management, J. Agr. Sci. London 145, 543-564.

Lavorel S., Garnier E. (2002) Predicting changes in community composition and ecosystem functioning from plant traits: revisiting the Holy Grail, Funct. Ecol. 16, 545-556.

Le Ber F., Benoit M. (1998) Modelling the spatial organization of land use in a farming territory. Example of a village in the Plateau Lorrain, Agronomie 18, 103-115.

Martin G., Duru M., Martin-Clouaire R., Rellier J.P., Theau J.P., Therond O., Hossard L. (2008) Towards a simulation-based study of grassland and animal management in livestock farming systems, in: Proceedings of the iEMSs Fourth Biennial Meeting, Barcelona, Catalonia, pp. 783-791.

Maurer K., Weyand A., Fischer M., Stöcklin J. (2006) Old cultural traditions, in addition to land use and topography, are shaping plant diversity of grasslands in the Alps, Biol. Conserv. 130, 438-446.

McCown R.L., Hammer G.L., Hargreaves J.N.G., Holzworth D.P., Freebairn D.M. (1996) APSIM: a novel software system for model development, model testing and simulation in agricultural systems research, Agr. Syst. 50, 255-271.

Parsons A.J. (1988) The effect of season and management on the grass growth of grass sward, in: Jones M.B., Lazenby A. (Eds.), The grass crop, Chapmann and Hall, London, pp. 129-178.

Steinfeld H., Gerber P., Wassenaar T., Castel V., Rosales M., Haan C. (2006) Livestock's long shadow: environmental issues and options, FAO, Rome.

Thenail C., Baudry J. (2004) Variation of farm spatial land use pattern according to the structure of the hedgerow network (bocage) landscape: a case study in northeast Brittany, Agr. Ecosyst. Environ. 101, 53-72.

Tichit M., Doyen L., Lemel J.Y., Renault O., Durant D. (2007) A coviability model of grazing and bird community management in farmland, Ecol. Model. 206, 277-293. 